\title{
Identity and the Ethics of Tolerance
}

\author{
Antoon Geels *
}

Abstract

Our self-image is constructed in the interplay between man and culture. Religious traditions play a key role in this interplay; myths create meaning to the individual and to society at large. Sacred narratives provide man with patterns of behavior, how life should be lived. The other side of the picture is that identity and integrity may lead to intolerance, a dividing line between them and us: the most serious obstacle to peace and intercultural understanding.

Religions can reinforce strong feelings of humiliation, of being a victim. This, in turn, may lead to the splitting of humanity into good and evil; one group demonizes the other. This coupled with an idealized, wrathful and punitive deity or leader may lead to violence, and violence is sanctified. Religion may encourage feelings of humiliation, but it can also deliver an antidote. There are theological resources that can counter terror and violence. A merciful and compassionate God can replace a wrathful and punitive deity.

A stage of faith known as gerotranscendence is characterised by "an increasing feeling of belonging to the universe". Representatives of 'glocal' spirituality reject claims of exclusivity. A glocal perspective is crucial. What we need today is that a greater number of spiritual leaders stand up and insist on values that touch upon the sanctity of life.

*Professor of Psychology of Religion, Lund University, Sweden; antoon.geels@toel.lu.se 
Keywords: Identity, Religion, Ethics, Tolerance, Violence

No man is an island,

Entire of itself,

Every man is a piece of the continent,

A part of the main. [...]

Any man's death diminishes me,

Because I am involved in mankind,

And therefore never send to know for whom the bell tolls;

It tolls for thee. (John Donne, 1572-1631)

\section{Introduction - Sacred Narrative and Identity}

Someone said, I think it was the philosopher Charles Taylor, that life is just a bowl full of stories. Man is a narrative being, from the cradle to the grave. Stories, including sacred narrative, help us to construct our identity. This process involves at least four aspects. First there is the historical dimension; that is our recollection of events in the past, retold, over and over again, in the present. Then we can identify a cultural dimension; culture provides the storyteller with different narrative models, for example literary genres, plot structures, metaphoric themes, etc. Cultural stories are connected to personal stories. Thirdly, there is a rhetorical dimension, emphasizing on what is being done through narrative via communicative interaction. And finally, we can discern an experiential dimension, pertaining to psychological experience, creating a sense of continuity and cultural connectedness. ${ }^{1}$ All these dimensions interact; leading to what Paul Ricœur calls a "narrative identity." 2

In the introductory part of this paper I will present a few comments on this concept of narrative identity, especially if it is defined too narrowly, leading, in some cases, to a 'them-versus-us' relation. I will then proceed to the issue of identity and tolerance. In the third and final part I will introduce the idea that our identity needs to be expanded in our globalized world. Support for this position can be collected from both contemporary theories about human development and the spiritual traditions in world religion.

${ }^{1}$ See, Freeman, Narrative integrity, 2001.

${ }^{2}$ Quoted in Crossley, Introducing Narrative Psychology, 2000, 50. 
Let's return, shortly, to the relation between narrative and identity. In his trailblazing book Sources of the Self: The Making of Modern Identity (1989), Charles Taylor writes that ideas about the self and ethics are interrelated. Our identity is influenced by the importance of things. The self is created through a "network of conversation". Narrative psychology is a link between the individual and culture.

The well-known anthropologist Clifford Geertz wrote in one of his most quoted essays: "there is no such thing as a human nature independent of culture." ${ }^{3}$ Our self-image is constructed in the interplay between man and culture.

It goes without saying that religious traditions play a key role in this interplay, not in the least when it comes to ethical conduct. As a matter of fact, religion plays an important role in providing man with stories. Since we are in India, let me just mention the Bhagavadgita, depicting a civil war between the Pandavas and Kauravas. One of the main characters is Arjuna, pondering about whether it is right to participate in this war. The text contains role models that can be adopted by the reader. In so-called original cultures, myths are being told over and over again, and made alive in ritual. Myths create meaning, not only to the individual but also to society at large.

Other examples can be selected from Jewish and Tibetan culture. Both are characterized by a strong cultural identity. In Tibetan culture the importance of biographical narratives, stories of famous lamas or historical saints such as Milarepa, is obvious. The ultraorthodox Jews in New York, namely the charedim, do their utmost to preserve their cultural identity in a society which has practically speaking diametrically opposed views. Many Jews actually work in the world out there, the pluralistic American world. How do they preserve their identity? The short answer is with the idea of a symbolic community, an imagined ghetto. This means that it does not really matter where the Jews are located. There is always an imagined community, which is portable, so to speak. Another aspect is that the charedim draw a sharp line

${ }^{3}$ Geertz, The Interpretation of Cultures, 1973, 49. 
between their own group and American society; they think in terms of them-versus-us. ${ }^{4}$

The examples mentioned above clearly demonstrate that sacred narrative provides man with patterns of behavior, how life should be lived, the "good life", or the "music" of our lives, as Shakespeare would have it. In our terms we could speak of narrative identity and integrity. An important aspect of this identity pertains to ethics. ${ }^{5}$

The other side of the picture is that identity and integrity may lead to intolerance, a dividing line between them and us. Thinking along these lines represents the most serious obstacle to peace and intercultural understanding. This blunt statement comes from V.C. Kool, a psychologist specialized in the psychology of non-violence. ${ }^{6}$ Most probably this way of thinking has deep evolutionary roots, which we cannot go into, due to space constraints. As a process, thinking in terms of them and us are related to the hunter-gatherer stage of human development. As a product it can be observed in such diverse activities as football hooligans and the behavior within extreme religious cults.

\section{Identity and the Limits of Tolerance}

When we expand our identity towards inclusiveness we will most likely increase the bounds of tolerance. The authors of a textbook on comparative ethics point at the fact that we are developing a global civilization; we are all interconnected, through mass media, the Internet, etc. In the introduction to the book they write: "No longer can any person, country, or religion be an island". This seems to be in sync with the fragment from John Donne with which the paper begins. The approach of the three scholars is contemporary and normative. Their aim is nothing less than to search for "a normative interreligious and cross-cultural or global

\footnotetext{
4 Åberg, Det föreställda ghettot, 2003, 21f.

${ }^{5}$ See, Freeman och Brockmeier, Narrative integrity, 2001, 75ff.

${ }^{6} \mathrm{Kool}$, Psychology of Nonviolence and Aggression, 2008, 100.
} 
ethics that will help us to decide what we ought to do about the challenges we face" 7 .

Another example of a scholar drawing normative conclusions from research is the American psychologist of religion James W. Jones. His study on the psychology of religious terrorism also addresses the issue of intolerance, of thinking in terms of we versus them. Jones emphasizes the ambiguity of religion, that religion sometimes is the problem, but that religion more often than not also contains the solution. An example is his analysis of the relation between a wrathful and punitive deity and violence in the name of God. The following general factors may lead to violence. Strong feelings of shame and humiliation, of being a victim, can be reinforced by religion. This, in turn, may lead to the splitting of humanity into good and evil; one group demonizes the other. This factor coupled with an idealized, wrathful and punitive deity or leader may lead to the conviction that purification in the form of a sacrifice is required, leading, in turn, to violence. A punitive God or leader requires purifying the world. Violence is sanctified. A graffito in Palestinian Gaza says: "Death in the way of Allah is life." 8

Jones underlined that religion also contains the opposite, as already stated. This is precisely what he means with the ambiguity of religion. Religion may encourage feelings of humiliation, but it can also deliver an antidote. Religion can and does teach empathy and compassion towards the other. There are theological resources that can counter terror and violence. In other words, critique often comes from within the religions themselves. A merciful and compassionate God can replace a wrathful and punitive deity. Jones turns to the mystical traditions in world religions in order to find inspiration for alternative views of God.

What we need today is that a greater number of spiritual leaders stand up and insist on values that touch upon the sanctity of life. And not only that, but also select passages from sacred narrative that speak about peace and reconciliation. In addition, we would

7 Fasching, Dechant \& Lantigua, Comparative Religious Ethics, 2011, 4ff.

8 Jones, Blood that cries out from the earth, 2008, chapter 6. 
like to see spiritual leaders providing rituals that mirror forgiveness and atonement. ${ }^{9}$

It is time I emphasized the idea of what I would call glocal spirituality. The word "glocal" is, as you will understand, a combination of local and global. In our globalized and interdependent world we are in great need of intercultural understanding without losing our own local perspective. Simultaneously we need to acknowledge the fact that other people have other stories. Representatives of glocal spirituality reject claims of exclusivity. I do think that the well known Indian guru Sri Sri. Ravi Shankar is a good example of this approach. Glocal spirituality has an inclusive view, without denying its own cultural and spiritual background. According to my judgment, a glocal perspective is of crucial importance. A glocal view might even save our planet.

Önver Cetrez, a colleague of mine, addresses this issue, although in other wording. He makes a distinction between including and excluding identity markers. His line of reasoning starts from a group of scholars who call themselves "Psychologists for Social Responsibility". In the $21^{\text {st }}$ century, people still construct their individual and group identity in relation to religious, ethnic, national and socio-economic characteristics. The inherent risk of strong identity markers is the thought patterns I have designated as "them versus us". According to Cetrez there are many people who feel disillusioned because they do not embrace a frame of reference that includes rather than excludes people. The models of identity offered by their nearest environment, or society at large, do not help them to create more including patterns of identity. They also lack role models that can inspire them to be world-citizens. ${ }^{10}$

I do think that Cetrez and the group of psychologists for social responsibility are right. We do need more role models, we do need a more including identity. Developmental psychologists and spiritual leaders deliver a similar message. Let me present just a few examples.

${ }^{9}$ Cf. Silberman, Religious Violence, Terrorism, and Peace, 2005.

10 Cetrez, Att möta oss själva i bilden av den andre, 2011, 147f. 


\section{Development toward Universalism}

Lawrence Kohlberg (1927-87) is well known for his scheme of moral development in six stages, organized in three main levels: pre-conventional, conventional, and post-conventional. The last mentioned develops during late adolescence and onward. The final stage is labeled as a "Universal ethical principle orientation". At this stage, the individual develops a capacity for empathy. However, this stage is rare. When Kohlberg presents examples of persons who in their lives demonstrate such ability, he mentions Mahatma Gandhi, Jesus, Buddha, and Martin Luther King.

It is important to remember that Kohlberg regards these six stages as hierarchically integrated. The insights of earlier stages are integrated in broader frameworks. Development is understood in terms of increasing differentiation and integration.

Kohlberg also maintains that development follows a similar course in different cultures. Although there are cultural differences, the underlining way of reasoning is the same, Kohlberg asserts. This conclusion is based on extensive interviews in countries such as Mexico, Taiwan, Turkey, Israel, Kenya, and India. ${ }^{11}$

James Fowler has presented a similar message, acknowledging the complexity of faith development. In his own summary of faith development (1996) Fowler describes the final stage in terms of universalizing faith. At the fifth stage, called conjunctive faith, the individual realizes that truth must be approached from multiple points of view, including symbol, ritual, and myth. This fifth stage "extends well beyond the bounds of social class, nation, race, gender, ideological affinity, and religious tradition." This process of extension and inclusion now comes to completion. Again, this stage is relatively rare. Individuals at this stage exhibit openness that is "grounded in a oneness with the power of being". ${ }^{12}$

About twenty years after the publication of Stages of Faith, Fowler summarizes a person with universalizing faith. Such a person "has assented to a radical decentration from the self as an

11 See Crain, Theories of Development, 1985.

12 Fowler, Pluralism and Oneness in Religious Experience, 1996, 170ff. 
epistemological and valuational reference point for construing the world and has begun to manifest the fruits of a powerful kind of kenosis, or emptying of self." This kenosis, he continues, is often described as "detachment" or "disinterestedness". Fowler then presents an extensive quote from Gandhi and some parts of the Bhagavadgita that inspired the Mahatma. He adds that additional examples could have been chosen from Buddhist, Christian, or Jewish sources. ${ }^{13}$

About the same time as Fowler published his seminal book Stages of Faith (1981), another developmental psychologist, Robert Kegan, published a book titled The Evolving Self (1982). Development passes through five levels, from institutional to inter-individual levels. The last mentioned "acknowledges and cultures capacity for interdependence, for self-surrender and intimacy, for interdependent self-definition" ${ }^{14}$

We cannot leave developmental theories without mentioning Erik Homburger Erikson (1902-1994) and the Swedish scholar Lars Tornstam. Erikson's well-known stages of development have been revised during, and even after, his life. The eighth stage is characterized by wisdom and integrity. After his death, Joan M. Erikson (his wife) completed the life cycle with her husband's research on the ninth stage. This stage is linked to the Swedish scholar Lars Tornstam and his research on what he called gerotranscendence. ${ }^{15} \mathrm{~A}$ major characteristic of this stage is "an increasing feeling of belonging to the universe". Other examples of changes in perspective include a decreasing interest in shallow social relations, a decreasing interest in material things, a decrease in self-centeredness, and more time spent in meditation and moments of quiet. ${ }^{16}$

13 Fowler, Becoming Adult, Becoming Christian, 2000, $54 \mathrm{ff}$.

14 Kegan, The Evolving Self, 1982, 227.

15 See Erikson, The Life Cycle Completed, 1998.

16 Tornstam, Åldrandets socialpsykologi, 2010, 297. 


\section{Universalism and Mysticism}

There is no room to comment on this interesting research, the common denominator of which is interconnectedness, integration, empathy, and universal ethics. It is my impression that the final stage of development, as described by Kohlberg, Fowler, Kegan, and Erikson is not as rare as they thought. The empirical research of Tornstam certainly shows that the characteristics of gerotranscendence are rather common in human development.

Let's now turn to the field of mysticism and spirituality. Do we find similar ideas about human development? I will focus on the idea of universalism, as opposed to particularism.

In the field of religion and spirituality we could begin with a keyword used by Brother Wayne Teasdale, in his beautiful book called The Mystic Heart: Discovering a universal spirituality in the world's religions (1999). According to Brother Teasdale we are at the dawn of a new consciousness, a new awareness, characterized by for example: (i) a growing sense of the rights of other species, (ii) a recognition of the interdependence of all domains of life and reality, (iii) a deep, evolving experience of community between and among the religions through their individual members, and (iv) an openness to the cosmos, with the realization that the relationship between humans and the earth is part of the larger community of the universe. ${ }^{17}$

Again, the message is to expand our identity into a more inclusive one. Within the spiritual traditions of the world this is a rather common view. One example in our time is Rabbi Bob Carroll. According to him there is a tension between universalism and particularism in the Jewish psyche. Israel shall be "a light for the Gentiles" (Isaiah 42:6). In Leviticus 19: 18 we read "love your neighbor as yourself". But who is my neighbor? Is it my fellowbeliever, or any other human being? Rabbi Carroll's position is that the universal message is superior. That is the fundamental message of the Bible: to show compassion to humanity at large. 18

\footnotetext{
${ }^{17}$ Teasdale, The Mystic Heart, 1999, 4.

${ }^{18}$ Carroll, "Have we not all one Father?," 2010, 63ff.
} 
Another example of this universal message in our time is M.R. Bawa Muhaiyaddeen, born in Sri Lanka. According to him, we share the inner essence of religion with all other religions. To be a Sufi, he writes, "is to bestow [...] love, kindness, compassion, and mercy on all creations. ${ }^{19}$

Let me add another example from contemporary spiritual wisdom. Dr. Ephraim Isaac is a Jewish peace-worker from Ethiopia. Dr. Isaac holds a degree from Harvard and is attached to the institute for Semitic studies at Princeton University. Dr. Isaac has received a number of distinctions for his work on peace and intercultural understanding. The prophet Isaiah has been a source of inspiration for him. The passage chosen by Dr. Isaac is Isaiah 58: 6-7, where the prophet mentions that we should "loose the chains of injustice" and "set the oppressed free".

Is it not to share your food with the hungry and to provide the poor wanderer with shelter when you see the naked, to clothe them, and not to turn away from your own flesh and blood?

Dr. Ephraim also quotes Isaiah 2:4, the passage where the prophet says that our swords will be turned into plowshares, and our spears into pruning hooks. Dr. Isaac also shares Isaiah's vision of a time to come, a time of peace and reconciliation, a time when the wolf will live with the lamb, the leopard will lie down with the goat, a time when there will be no more evil and wrong-doing. Dr. Ephraim Isaac chose the God of love.

My final example is again from contemporary Jewish spirituality. Rabbi Isak Kook (d. 1935) tried to build bridges between the religions of the world. Spiritual truth is so extensive, so rich, that it is impossible to express them through the lens of one tradition alone. All human truths are partial. We experience glimpses of a reality that we only partly can perceive. Rabbi Kook rejects all claims of absolute truth. The religions of the world must be understood as complementary interpretations. When we struggle

${ }^{19}$ Retrieved from http:/ / www.bmf.org/ramadan/ sufism.html on June 16, 2011. 
with these truths, it is possible to remove the veils that cover reality, as we know it.

It is a challenge for spiritual leaders to stimulate believers to reach beyond their own spiritual identity and open up for the spiritual traditions of the world. This is a way to get closer to the divine or God, that God who is "good to all", who "has compassion on all he has made" (Psalm 145:9).20

\section{References}

Åberg, Johan. Det föreställda ghettot. Ultraortodox gränsdragning och identitetskonstruktion. The Jewish Observer. Malmö: Arcus, 2003.

Brockmeier, Jens \& Carbaugh, Donal. Narrative and Identity. Studies in Autobiography, Self and Culture. Amsterdam/Philadelphia: John Benjamins Publishing, 2001.

Carroll, Bob. "Have we not all one Father?" Toward a Psychohistory of the Jewish Idea of Compassion. Balslev, Anindita \& Evers, Dirk, Compassion in the World's Religions. Envisioning Human Solidarity. Münset: Lit Verlag, s., 2010, 53-72.

Cetrez, Önver. Att möta oss själva i bilden av den andre. DeMarinis, Valerie; Wikström, Owe; Cetrez, Önver, Inspiration till religionspsykologin - kultur, hälsa och mening. Stockholm: Natur och Kultur, s., 2011, 143-152.

Crain, W.C. Theories of Development. Harlow, Essex: Prentice-Hall, 1985, 118-136.

Crossley, Michele L. Introducing Narrative Psychology. Self, Trauma and the Construction of Meaning. Buckingham: Open University Press, 2000.

Erikson, Erik H. The Life Cycle Completed. Extended Version with New Chapters on the Ninth Stage of Development by Joan M. Erikson. New York: W.W. Norton, 1998.

Fasching, Darrell J. \& Dechant, Dell \& Lantigua, David M. Comparative Religious Ethics. A Narrative Approach to Global Ethics. Second Edition. Chichester: Wiley-Blackwell, 2011.

Fowler, James W. Pluralism and Oneness in Religious Experience: William James, Faith-Development theory, and Clinical Practice. Shafranske,

${ }^{20}$ Carroll, "Have we not all one Father?," 2010, 67ff. Carrolls tolkning får stöd av Ariel (1988:184) som skriver att Kook försökte nå bortom judendomens ortodoxa och slutna anspråk, till förmån för ett sökande efter universella värden och ideal. 
Edward P. (Ed.) Religion and the Clinical Practice of Psychology. Washington: American Psychological Association, 1996, 165-186.

Fowler, James W. Becoming Adult, Becoming Christian. Adult Development and Christian Faith. San Francisco: Jossey-Bass Publishers, 2000.

Freeman, Mark \& Brockmeier, Jens. Narrative integrity. Autobiographical identity and the meaning of the "good life". Brockmeier, Jens \& Carbaugh, Donal. Narrative and Identity. Studies in Autobiography, Self and Culture. Amsterdam/Philadelphia: John Benjamins Publishing, s., 2001, 75-99.

Geertz, Clifford. The Interpretation of Cultures. New York: Basic Books, 1973.

Jones, James W. Blood that cries out from the earth. The psychology of religious terrorism. New York: Oxford University Press, 2008.

Kegan, Robert. The Evolving Self. Problem and Process in Human Development. Cambridge, Mass.: Harvard University Press, 1982.

Kool, V.K. Psychology of Nonviolence and Aggression. New York: Palgrave Macmillan, 2008.

Silberman, Israela. Religious Violence, Terrorism, and Peace: A Meaningsystem Analysis. Paloutzian, Raymond F. \& Park, Crystal L. (Red.) Handbook of the.Psychology of Religion and Spirituality. New York \& London: The Guilford Press, s., 2005, 529-549.

Teasdale, Wayne. The Mystic Heart. Discovering a Universal Spirituality in the World's Religions. Novato, California: New World Library, 1999.

Tornstam, Lars. Åldrandets socialpsykologi. Stockholm: Norstedts, 2010. 